\title{
Asthma, allergies and respiratory symptoms in different activity groups of swimmers exercising in swimming halls
}

\author{
Marja Päivinen ${ }^{1,2^{*}}$, Kari Keskinen ${ }^{3}$, Tuula Putus ${ }^{1}$, Urho M. Kujala ${ }^{3}$, Pentti Kalliokoski ${ }^{4}$ and Heikki O. Tikkanen ${ }^{5}$
}

\begin{abstract}
Background: Respiratory symptoms are common in competitive swimmers. However, among these and in swimmers at other activity levels the swimming distance, the total spent time in swimming halls and their medical background varies. Our objectives were, first, to assess their medical histories and the associations with respiratory symptoms among swimmers in different activity groups and then second, to study the pulmonary function findings and related medications in competitive swimmers who exercise in swimming hall environments the most.

Methods: First, 1118 participants consisting of 133 competitive-, 734 fitness- and 251 occasional swimmers answered questionnaires concerning their medical background, their respiratory symptoms in connection to swimming distance and their amount of time spent in swimming halls. Secondly, in 130 competitive swimmers, pulmonary function was tested by spirometry and a specific questionnaire was used to assess respiratory symptoms, medical histories and prescribed medication.
\end{abstract}

Results: Respiratory symptoms were reported by $18 \%$ of the studied swimmers. Competitive swimmers had significantly more symptoms than fitness- and occasional swimmers. Naturally competitive swimmers swum more than $2000 \mathrm{~m}$ and stayed by the pool more than $90 \mathrm{~min}$, longer than the other activity groups of swimmers. Spirometry testing showed airway obstruction in 15 swimmers, which was 12\% of the 130 competitive swimmers. 21 of them, had physician-diagnosed asthma and 16 of these individuals had prescribed medication for it.

Conclusions: Competitive swimmers had the highest swimming hall exposure and reported significantly more respiratory symptoms. A high prevalence of airway obstruction findings in competitive swimmers with asthma and allergies suggests a need for future recommendations for regular testing and special medical care for competitive swimmers.

Keywords: Asthma, Allergy, Respiratory symptoms, Pulmonary function, Swimming halls, Swimming

\section{Background}

A swimming hall environment, and especially exposure to airborne trichloroamine and related adverse effects on respiratory health, have been intensively investigated in several studies [1-9]. Swimming is recommended as

*Correspondence: marja.paivinen@utu.fi

1 Department of Occupational Medicine, Faculty of Medicine, University of Turku, Turku, Finland

Full list of author information is available at the end of the article a suitable mode of exercise for persons with asthma and allergies [10-16]].

Swimming induces less respiratory symptoms than other endurance modes of exercise like running or cycling at the same exercise intensity [10-12, 17, 18]. However, among competitive swimmers, the prevalence of respiratory symptoms, such as wheezing, shortness of breath, coughing and mucus production from airways, is reported higher than in the general population $[3,8,19-$ 23]. Thus, Dropnik et al. [20] suggested, that competitive original author(s) and the source, provide a link to the Creative Commons licence, and indicate if changes were made. The images or other third party material in this article are included in the article's Creative Commons licence, unless indicated otherwise in a credit line to the material. If material is not included in the article's Creative Commons licence and your intended use is not permitted by statutory regulation or exceeds the permitted use, you will need to obtain permission directly from the copyright holder. To view a copy of this licence, visit http://creativecommons.org/licenses/by/4.0/. The Creative Commons Public Domain Dedication waiver (http://creativecommons.org/publicdomain/zero/1.0/) applies to the data made available in this article, unless otherwise stated in a credit line to the data. 
swimmers with higher intensities and training volumes are exposed to a swimming hall environment more in comparison to those with lower swimming intensities and shorter stays in a swimming pool area. In a study of competitive swimmers, however, the exposure to a swimming hall environment during training years or in weekly training sessions did not associate with respiratory symptoms [21]. In addition, previously the airborne trichloroamine levels in studied swimming halls were low and well below the proposed standard [24]. Therefore, chemical exposure may not be the only explanation and underlying factor for reported respiratory symptoms in connection to swimming. Understanding the role of other factors may require more investigation.

A swimmer's medical history such as physician-diagnosed asthma, allergies and previous respiratory infection, was a significant underlying factor for reported respiratory symptoms in competitive swimmers [21]. However, studies of the reported symptoms and medical histories among other swimmer activity groups, who use swimming halls, are lacking. Therefore, the aim of this study was to investigate asthma, allergies and respiratory symptoms together with the related exposure to a swimming hall environment in three activity groups and to study further the reported respiratory symptoms, medical histories, pulmonary function and prescribed medication in highly, trained active competitive swimmers.

\section{Methods}

\section{Subjects}

The study subjects using swimming halls were divided into three different groups according to their physical activity level by self-assessment. First, 1118 study participants consisting of competitive-, fitness- and occasional swimmers were examined with a modified structured questionnaire. Then, the training frequency, swimming distance and stay at a swimming pool area were also asked (Table 1).

Secondly, 130 competitive swimmers participated in both pulmonary function testing and questionnaire surveys. Pulmonary function by spirometry was performed in 130 active and competitive swimmers. Each swimmer was a member of a competitive swimming training team and had a significant swimming training history for several years.

\section{Questionnaire}

Swimming hall users $(\mathrm{N}=1118)$ were asked to participate in the study by filling a structured questionnaire modified from previously used questionnaire [21, 25]. The questionnaire included questions concerning medical history, swimming background and reporting of respiratory symptoms. The medical history of physiciandiagnosed asthma and allergies was documented. The swimming distance in meters, time spent at the pool area and number of weekly training sessions were asked. The questionnaires were collected at five different swimming halls located in different parts of Finland.

\section{Collection of data}

Questionnaire data for the swimming hall customer study were collected in swimming halls, suchthat every swimmer could participate in the study within a threeweek periodtaking place in the autumn. Autumn allowed for the for any exclusion possible effects of a pollen season on the reporting of respiratory symptoms. There was no information about the exact number of customers during those days in the swimming halls, so the exact participation rates could not be calculated. All swimmers, who participated in pulmonary function testing, filled the questionnaire in connection to the pulmonary function testing.

A specially modified questionnaire was used for the 130 competitive swimmers who participated in spirometry testing (Table 1). All competitive swimmers participated in national swimming championships and had a training history of competitive swimming for 8 years on average. The questionnaire included further questions concerning medical family history and prevalence of respiratory symptoms at different swimming training intensities. The intensities were categorized into five different training zones. Those intensities are known among competitive

Table 1 Summary of methods and demographics of the study target groups

\begin{tabular}{|c|c|c|c|c|c|c|c|c|}
\hline $\begin{array}{l}\text { Study } \\
\text { method }\end{array}$ & Swimmer population, $\mathrm{N}$ & $\begin{array}{l}\text { Gender } \\
\text { F/M }\end{array}$ & $\begin{array}{l}\text { Mean age } \\
\text { (yr) }\end{array}$ & $\begin{array}{l}\text { Distance swam } \\
\text { per session } \\
\text { (meters) }\end{array}$ & $\begin{array}{l}\text { Stay at } \\
\text { swimming } \\
\text { pool area } \\
\text { (minutes) }\end{array}$ & $\begin{array}{l}\text { Asthma } \\
\text { Prevalence } \\
\%\end{array}$ & $\begin{array}{l}\text { Allergy } \\
\text { Prevalence } \\
\%\end{array}$ & $\begin{array}{l}\text { Respiratory } \\
\text { symptoms } \\
\text { Prevalence } \\
\%\end{array}$ \\
\hline Questionnaire & $\begin{array}{l}1118 \text { Swimmers: } \\
251 \text { Occasional } \\
734 \text { Fitness } \\
133 \text { Competitive }\end{array}$ & $\begin{array}{l}650 / 468 \\
169 / 82 \\
426 / 308 \\
55 / 78\end{array}$ & $\begin{array}{l}43(19) \\
39(19) \\
48(16) \\
20(12)\end{array}$ & $\begin{array}{l}1215 \\
543 \\
993 \\
3418\end{array}$ & $\begin{array}{l}63 \\
60 \\
56 \\
117\end{array}$ & $\begin{array}{l}9 \\
12 \\
8 \\
13\end{array}$ & $\begin{array}{l}23 \\
23 \\
22 \\
28\end{array}$ & $\begin{array}{l}18 \\
13 \\
16 \\
44\end{array}$ \\
\hline Spirometry & 130 Competitive & $58 / 72$ & $17(3)$ & 5600 & 120 & 20 & 31 & 45 \\
\hline
\end{tabular}


swimmers, because they are taught and monitored by coaches during training sessions.

\section{Pulmonary function testing}

Highly trained competitive swimmers $(\mathrm{N}=130 ; 58$ females and 72 males) participated in both pulmonary function testing and the questionnaire survey. The mean age of the swimmers was 17 years ( $\mathrm{SD} \pm 3$ years). All of the studied swimmers were participants of national swimming championships with a training history of competitive swimming for 8 years and weekly training sessions of $18 \mathrm{~h}$ on average.

Spirometry was measured with a Spiro Star 2000 spirometer (Medikro, Kuopio, Finland) according to the ATS and ERS guidelines [26, 27]. Spirometry results were expressed as a percent of personal age and size- and sexmatched predicted values [28] or for Finnish children under 18 years [29], according to the most recent ATS and ERS criteria. Forced vital capacity (FVC) and forced expiratory volume in one second $\left(\mathrm{FEV}_{1}\right)$ and their ratio $\left(\mathrm{FEV}_{1} / \mathrm{FVC}\right)$ were analyzed. Airway obstruction was defined by the criteria used in relation to the age, size and sex matched predicted values. Airway obstruction required a finding of $\mathrm{FEV}_{1} / \mathrm{FVC}<88 \%$ of predicted. All studied competitive swimmers were non-smokers.

\section{Medication prescribed for the swimmers}

The medication data were collected and classified by the ATC index from all swimmers participating in spirometry testing.

\section{Ethics}

The ethical considerations for the questionnaire and pulmonary function testing on land were evaluated bythe ethics Committee of Helsinki and Uusimaa hospital district.

\section{Statistical methods}

Odds ratios (OR) together with confidence intervals for reported respiratory symptoms between different risk factor categories were calculated by multiple logistic regression analysis. In this study, the outcome was reported as respiratory symptoms or no respiratory symptoms. Explanatory variables in the model were the activity group (i.e., competitive, fitness or occasional), type of swimming hall, sex and age. In separate models, swimming distance and time spent in the pool area were used. However, in these models the activity group was naturally confounded and a stronger predictor. Therefore, we ran also separate models using swimming distance and the time spent in a swimming hall as well as the type of swimming hall, sex and age but not the activity group. Different cutoffs were assessed, and the greater than 90-min or less than 90-min cutoffs were optimal for time spent. Similarly, for distance, an optimal cutoff of less than $2000 \mathrm{~m}$ and greater than $2000 \mathrm{~m}$ was used. A P value of less than 0.05 (two tailed) was considered as statistically significant. The data analysis for this study was generated by using SAS software, version 9.4 of the SAS system for Windows (SAS Institute Inc., Gary, NC, USA).

\section{Results}

The prevalence of respiratory symptoms, while swimming, was $18 \%$, when all three activity groups were observed together. The prevalence of physician-diagnosed asthma and allergy was $7 \%$, only asthma was $2 \%$ and only allergy was $16 \%$. Neither asthma nor allergy was reported by 836 or $75 \%$ of the swimming hall swimmers. The medical histories of physician-diagnosed asthma, allergy and reported respiratory symptoms in different populations of swimmers in swimming halls are shown in Table 1.

A comparison among different groups of swimmers showed that competitive swimmers reported significantly more respiratory symptoms while swimming than fitness and occasional swimmers (Fig. 1). OR for reporting respiratory symptoms in competitive swimmers were 2.31 (95\% CI 1.41-3.80, $P<0.0001)$ compared to fitness swimmers and 5.27 (95\% CI 3.19-8.69, $P<0.0001$ ) compared to occasional swimmers (Fig. 1).

The highest risk for reported symptoms was observed by the activity group competitive swimmers with a medical history of asthma and allergy. The calculations showed that there were no significant differences between different swimming halls, age or sex (Fig. 2).

Among those with asthma risk for reported respiratory symptoms, they did not differ between different activity groups. However, the risk for reported respiratory symptoms was significantly higher in competitive swimmers who reported only allergy $(P=0.001)$ or neither asthma nor allergy $(P<0.0001)$ in comparison to other swimming hall users, fitness swimmers and occasional swimmers.

Examinations on the exposure to a swimming hall environment showed no association between reported symptoms and time spent at the pool area, when the time was less than $90 \mathrm{~min}$. However, the swimmers who spent time in a swimming pool area for more than 90 min reported significantly more respiratory symptoms (OR 2.66, 95\% CI1.91--3.71, $P<0.0001$ ) (Fig. 3). This result, however, is strongly associated with the activity group and the fact that the competitive swimmers spent approximately a mean of two hours in the pool area per swimming session, when fitness- and occasional swimmers spent approximately a mean of one hour (Table 1 ). When additional analyses without the activity group was performed, the time spent factor $(<90 \mathrm{~min}, \geq 90 \mathrm{~min})$ was significant 

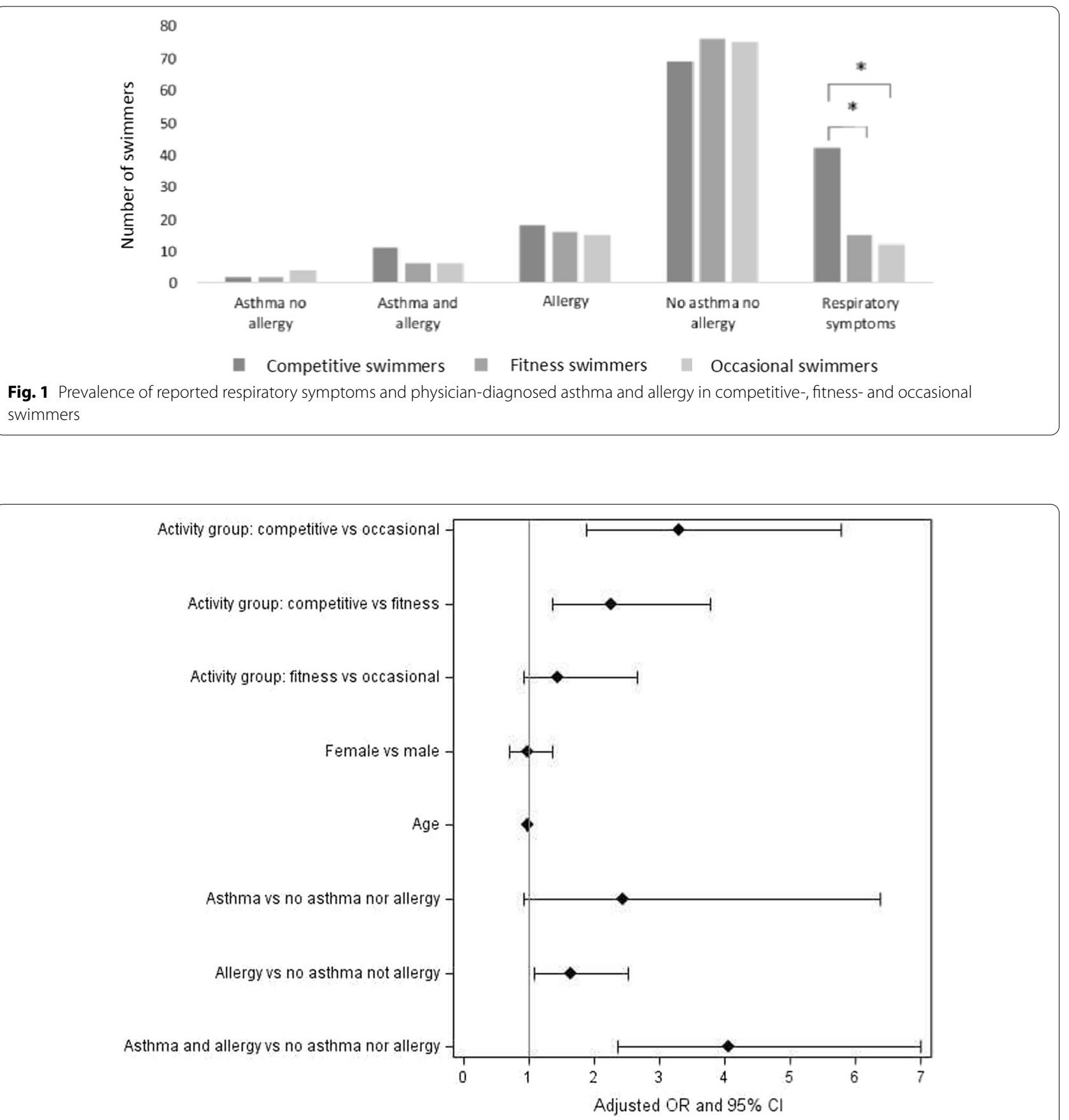

Fig. 2 Odds ratio (OR) for respiratory symptoms when activity group, sex, age and medical histories were observed

$(P=0.027)$ when adjusted with factors of swimming hall type, sex and age.

There was no association with reported symptoms and distance swum in meters even with less than $2000 \mathrm{~m}$ swum. However, the swimmers, who swam more than $2000 \mathrm{~m}$, reported respiratory symptoms significantly more (OR 2.91, 95\% CI 2.02-4.17, $P<0.0001$ ) compared to the others (Fig. 4). These swimmers were mainly competitive swimmers. This result, however, was also strongly associated with the activity group. The competitive swimmers swum approximately a mean of $3.5 \mathrm{~km}$, when fitness swimmers swum approximately $1 \mathrm{~km}$ and occasional swimmers swum approximately $0.5 \mathrm{~km}$ per swimming session (Table 1 ). When 


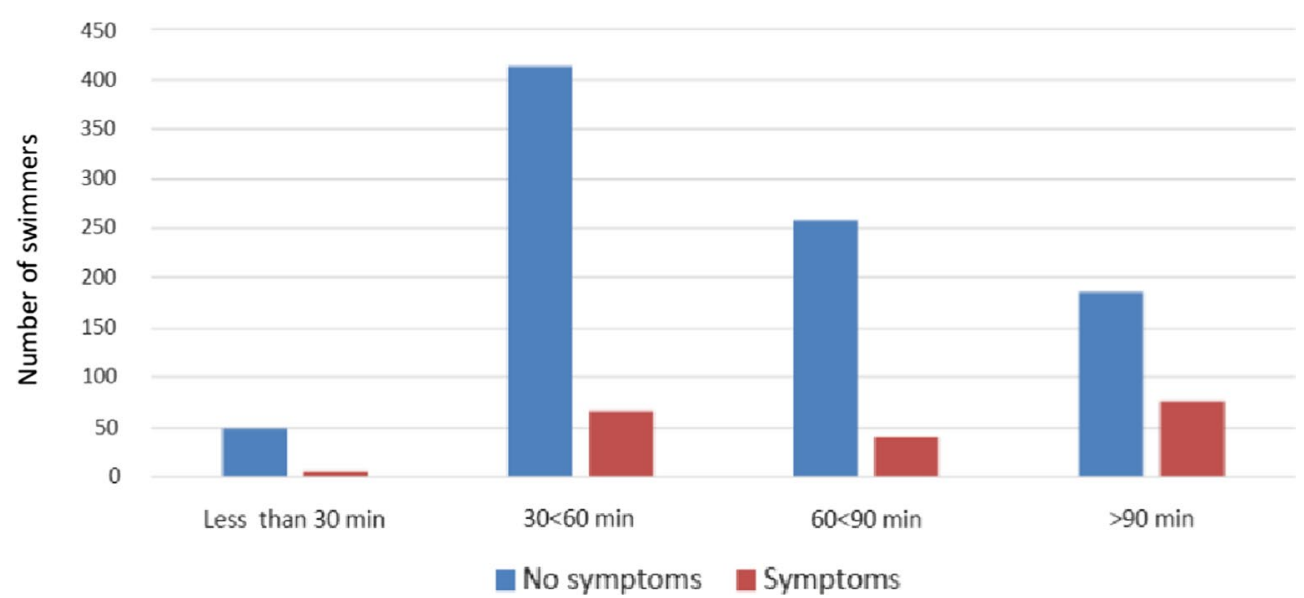

Fig. 3 Reported respiratory symptoms by swimming hall users according to the time spent at the swimming pool area was less than 30 min, 30-60 min, 60-90 min or greater 90 min

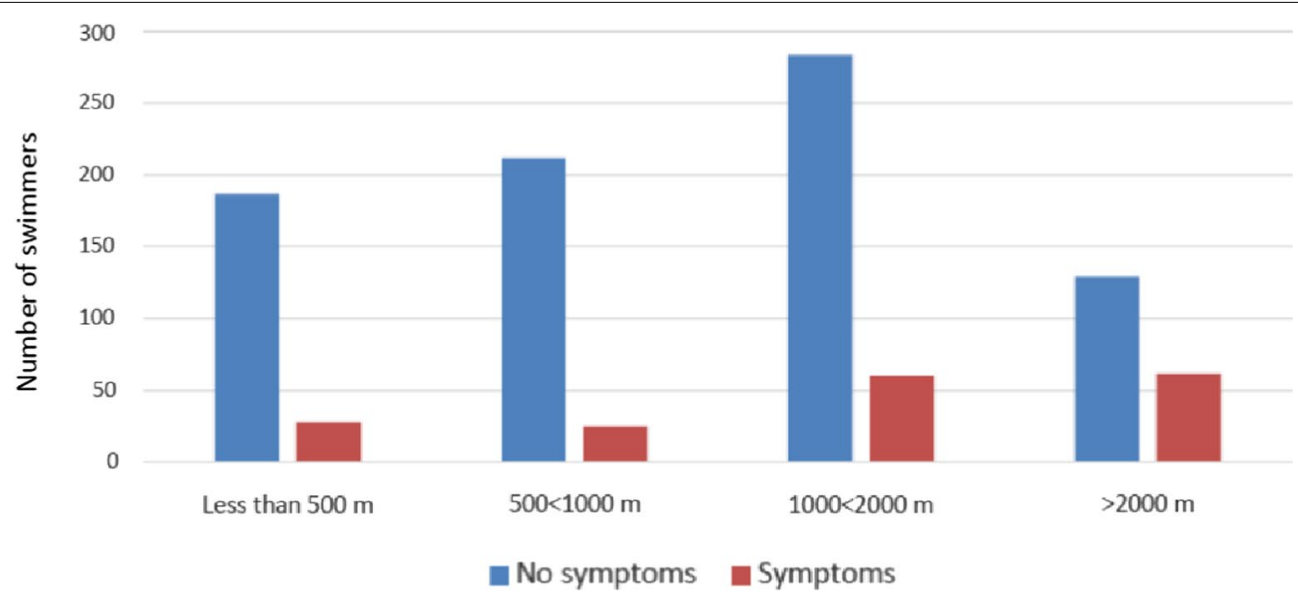

Fig. 4 Reported respiratory symptoms in swimming hall users according to a swimming distance of less than $500 \mathrm{~m}$, greater than $500 \mathrm{~m}$ but less than 1000, greater than $1000 \mathrm{~m}$, greater than $1000 \mathrm{~m}$ but less than $2000 \mathrm{~m}$ or greater than $2000 \mathrm{~m}$

additional analyses without the activity group was performed, the distance factor $(<2000 \mathrm{~m}, \geq 2000 \mathrm{~m})$ was significant $(P=0.0041)$ when adjusted with swimming hall type, sex and age.

Spirometry testing showed that the competitive swimmers had a baseline $\mathrm{FEV}_{1}$ and FVC mean of approximately $110 \%$ of predicted, and airway obstruction was found in $12 \%$ of the studied swimmers (Table 2). All obstruction findings were found in swimmers with physician-diagnosed asthma (Fig. 5). Surprisingly, almost all, except for two, of the swimmers with an obstruction finding, were males.

Spirometry findings, respiratory symptoms and the physician-prescribed medication were studied together (Table 3). Five of the swimmers with asthma and airway obstruction reported no medication and all of them were males.

This study showed no differences between the training habits in swimmers using physician-prescribed medication and swimmers using no medication.

\section{Discussion \\ Different populations}

The majority of swimmers did not report any respiratory symptoms while swimming (Fig. 1) including those with physician-diagnosed asthma and allergy. During vigorous exercise, respiratory symptoms are typically observed in $90 \%$ of asthmatics. In this study, among swimmers in swimming halls with physician-diagnosed asthma, the prevalence of reported respiratory symptoms while 
Table 2 Spirometry findings in 130 competitive swimmers

\begin{tabular}{llll}
\hline & All swimmers $\mathbf{N}=\mathbf{1 3 0}$ & Female swimmers $\mathbf{N}=\mathbf{5 8}$ & Male swimmers $\mathbf{N}=\mathbf{7 2}$ \\
\hline FVC mean (SD) & $112 \%(12)$ of predicted & $111 \%(13)$ of predicted & $112 \%(12)$ of predicted \\
FEV1 mean (SD) & $108) \%(13$ of predicted & $110 \%(13)$ of predicted & $106 \%(12)$ of predicted \\
FEV1/FVC mean (SD) & $97 \%(9)$ of predicted & $99 \%(8)$ of predicted & $95 \%(9)$ of predicted \\
Airway obstruction n/N (\%) & $15 / 130(12 \%)$ & $3 / 58$ & $12 / 72$ \\
Asthma n/N (\%) & $25 / 130(19 \%)$ & $11 / 58$ & $14 / 72$ \\
\hline
\end{tabular}

$\mathrm{FEV}_{1}$ : Forced expiratory volume in one second (liters per second)

$\mathrm{FEV}_{1} / \mathrm{FVC}$ : Ratio of Forced expiratory volume in one second and forced vital capacity (\%)

FVC: Forced vital capacity (liters)

SD: Standard deviation

$\mathrm{N}$ : Number of subjects

$\mathrm{n} / \mathrm{N}$ : Number of subjects concerned out of the whole population number of subjects

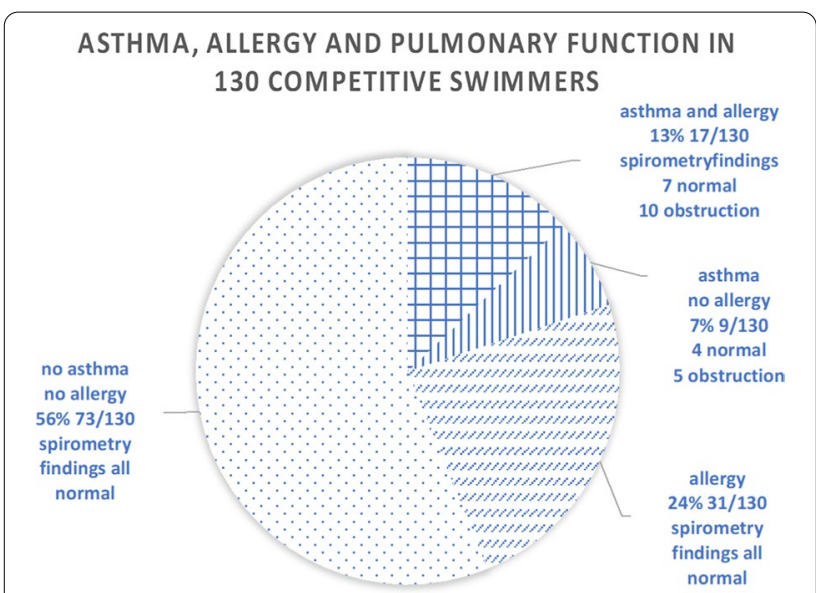

Fig. 5 Asthma, allergies and pulmonary function findings in 130 highly trained competitive swimmers

swimming was approximately one-third of that. This confirms the previously reported findings demonstrating the low asthmogenity of swimming [10-13].

Comparisons among different activity groups being competitive, fitness and occasional swimmers showed that the competitive swimmers reported respiratory symptoms three times more often than the fitness and occasional swimmers (Fig. 1). All activity groups were swimming in the same environment of a swimming hall and were exposed to similar environmental conditions.

The subjects' medical histories showed that those, who had physician-diagnosed allergy or had neither asthma nor allergy, had a significantly higher risk for respiratory symptoms than if they were competitive swimmers in comparison to other activity groups such as fitness swimmers and occasional swimmers (Table 2). This finding suggests that there are special factors in competitive swimming that cause reporting of respiratory symptoms. Those special factors might connect to physical exercise strain, i.e., training intensity, a water environment and being immersed.

\section{Time and distance for exposure}

The present study showed that the length of stay under 90 min at the swimming pool area or having a swimming distance under $2000 \mathrm{~m}$ did not associate with reported respiratory symptoms. Typically, competitive swimmers spent time in the swimming pool area for more than $90 \mathrm{~min}$ and the swimming distance was far more than $2000 \mathrm{~m}$ (Table 1). Thus, these findings are consistent with the study of Dropnik et al. [20], who suggested that competitive swimmers are exposed to swimming hall disinfection by- products more than other activity groups in swimming halls due to the higher pulmonary ventilation during the time spent in the swimming pools. This finding of the higher prevalence of respiratory symptoms in competitive swimmers is consistent with a previous study [21]. Therefore, the exposure of competitive swimmers to the airborne trichloroamine in swimming halls may be increased by the greater amount of distance swum, and the time spent in the swimming pool area as well as the higher intensity of the physical exercise and higher ventilation rate. These factors may play a role in the increased prevalence of respiratory symptoms in competitive swimmers in comparison to other activity groups in swimming halls.

The maintenance of swimming halls, as a whole, meets the high requirements of optimal ventilation, hygiene, moisture and temperature controlling. A previous study showed that the airborne trichloroamine levels were low in swimming halls and followed the EU standards $[22,30]$. Reporting of respiratory symptoms decreased after the renovation of swimming halls in Finland [31]. These findings suggest that there might be structural factors in swimming halls affecting respiratory symptoms. This suggests that renewal and good maintenance 
Table 3 Spirometry findings, medication classified by ATC (www.whocc.no/atc_ddd_index/) and reported respiratory symptoms in 130 competitive swimmers that qualified for National Swimming Championships. The population was grouped according to physician-diagnosed asthma and allergy, physician-diagnosed asthma without allergy, physician-diagnosed allergy and no asthma and no allergy

\begin{tabular}{|c|c|c|c|c|}
\hline $\begin{array}{l}\text { Swimmers with physician } \\
\text { diagnosed }\end{array}$ & $\begin{array}{l}\text { Spirometry } \\
\text { finding: } \\
\text { Normal } \\
\text { Obstruction § }\end{array}$ & & $\begin{array}{l}\text { Medication ATC classification } \\
\text { (number of swimmers received prescription) }\end{array}$ & Respiratory symptoms \\
\hline $\begin{array}{l}\text { Asthma and allergy } N=17 \\
\S\end{array}$ & 10 & 7 & $\begin{array}{l}\text { - Respiratory system nasal preparations } \\
\text { R01AD11 (1) • } \\
\text { R01BA52 (1) • } \\
\text { * Respiratory system drugs for obstructive airway diseases, adrenergics, } \\
\text { inhalants } \\
\text { R03AC02 (7)* } \\
\text { R03AK06 (4)* } \\
\text { R03AC03 (2)* } \\
\text { R03AC13 (1)* } \\
\text { R03AK07 (2)* } \\
\text { R03BA02 (4)* } \\
\text { R03BA05 (1)* } \\
\text { R03BA05 (1)* } \\
\times \text { Respiratory system antihistamines for systemic use, aminoalkyl ethers } \\
\text { R06AE07 (1) × } \\
\text { R06AE09 (1) } \\
\text { R06AX22 (2) } \times \\
\text { - Sensory organs ophthalmological drugs decongestants and antial- } \\
\text { lergics } \\
\text { S01GX01 (1) • }\end{array}$ & 12 out of 17 \\
\hline Asthma & 6 & 3 & $\begin{array}{l}\text { * Respiratory system drugs for obstructive airway diseases, adrenergics, } \\
\text { inhalants } \\
\text { R03AC02 (4)* } \\
\text { R03AC13 (1)* } \\
\text { R03AK06 (2)* } \\
\text { R03AK07 (3)* } \\
\text { R03BA02 (1)* } \\
\text { R03BA05 (1)* } \\
\text { R03BA05 (1)* } \\
\text { R03DC03 (1)* } \\
\text { - Sensory organs ophthalmological drugs decongestants and antial- } \\
\text { lergics } \\
\text { S01GX01 (1) }\end{array}$ & 7 out of 9 \\
\hline Allergy $N=31$ & 31 & 0 & $\begin{array}{l}\times \text { Respiratory system antihistamines for systemic use, aminoalkyl ethers } \\
\text { R06AE09 (1) } \times \\
\text { R06AE07 (1) } \times \\
\text { - Sensory organs ophthalmological drugs decongestants and antial- } \\
\text { lergics } \\
\text { S01GX08 (1) }\end{array}$ & 18 out of 31 \\
\hline $\begin{array}{l}\text { No asthma and no allergy } \\
N=73\end{array}$ & 73 & 0 & - & 9 out of 73 \\
\hline
\end{tabular}

${ }^{\S}$ Five swimmers with asthma and airway obstruction did not report medication usage

of the swimming halls may play a role in reported respiratory symptoms in swimming halls. For example, in moisture-damaged buildings toxic substances in indoor air may cause airway infections, sinusitis and bronchitis and affect respiratory symptoms. In addition, a previous study showed that the mold exposure in schools associates with elevated mold-specific IgG levels and sinusitis in teachers [32]. This study`s results are similarities with reported respiratory symptoms previously found in competitive swimmers [21]. In the previous study, sinusitis was a significant risk factor for reported respiratory symptoms in competitive swimmers [21]. However, in the studied swimming halls, no significant amounts of microbes were found [30].

There is a need for a comprehensive scientific discussion for suggestions to optimize the exposure time in the swimming hall environment for competitive swimmers. The results of this study present this need for an additional consideration concerning the medical history and combined effects of competitive swimming and water 
environment-specific testing for identifying the underlying risk factors for respiratory symptoms and pulmonary disease.

\section{Pulmonary function findings concerning asthma and allergy with prescribed medication and symptoms}

Spirometry at baseline showed that the FVC in both female and male competitive swimmers was approximately $110 \%$ of predicted, which is suggested to be a typical finding in highly fit elite competitive swimmers $[3,22,33-35]$. In the present study, the body composition of competitive swimmers, such as BMI, height and weight, was consistent with those reported in elite swimmers [36].

Previous studies suggest that voluminous swimming training during childhood and adolescence stimulates lung tissue growth [37]. It is notable that when typical competitive swimmers' baseline spirometry result levels are $110 \%$ of predicted, the finding of $100 \%$ of predicted in an elite swimmer may mean that the value is a significantly lowered one for that individual. Thus, a "normal" spirometry finding in a competitive swimmer may give a misleading statement about the condition of a competitive swimmer`s pulmonary function.

The prevalence of airway obstruction findings (12\%) was surprisingly high, especially because airway obstruction was mainly found in male swimmers with asthma, who did not report any respiratory symptoms during swimming. Asthmatic male swimmers had more often childhood asthma, whereas in female swimmers, asthma was diagnosed during adolescence. It may be possible that in asthmatic males, whose previous asthma was in a remission phase, had a reduction in their asthma medication usage. Some of the swimmers with airway obstruction did not report medication despite an asthma diagnosis. However, worsening of pulmonary function in asthmatic males may develop slowly without notice and airway obstruction may exist, because asthmatic male swimmers remain asymptomatic while swimming [22]. The opposite situation in female swimmers may occur. When asthmatic females sense respiratory symptoms while swimming, they will seek for medical treatment and take physician-prescribed medication. Furthermore, sensing respiratory symptoms while swimming may cause a female swimmer to avoid developing an airway obstruction. An airway obstruction finding did not associate with reported respiratory symptoms. However, in previous studies, the lowered $\mathrm{FEV}_{1} /$ FVC associated with reported respiratory symptoms in competitive swimmers $[22,38]$. The medication data were collected from the 130 competitive swimmers, who qualified for the National Championships, participated in the pulmonary function testing and the questionnaire survey. The reported physician-prescribed medication is shown in Table 3. These findings of spirometry and the questionnaire study may suggest, that the medication was mainly well balanced in asthmatic female swimmers, and a special attention on the testing and medication on asymptomatic male swimmers with asthma may be required.

\section{Conclusions}

Swimming hall exposure, as the length of time spent at the pool area or the swimming distance, did not associate with the respiratory symptoms until swimmers exceeded $90 \mathrm{~min}$ or $2000 \mathrm{~m}$. Typically, during competitive swimming training, the exposures are higher. Among the activity groups in swimming halls, competitive swimmers reported three times more respiratory symptoms than the other groups.

Pulmonary function findings in competitive swimmers with a $12 \%$ prevalence of airway obstruction were surprisingly high. Therefore, attention should be paid on competitive swimmers' pulmonary health and tested through spirometry regularly to make sure that the medication is sufficient especially in those with a sensitivity of asthma and allergy.

\section{Abbreviations \\ ATS: American Thoracic Society; ERS: European Respiratory Society; FEV ${ }_{1}$ : Forced expiratory volume in one second, liters $\left(I_{;} F E V_{1} / F V C\right.$ : Ratio of forced expiratory volume in one second and forced vital capacity (\%); FVC: Forced vital capacity, liters (I); N: Number of subjects; n/N: Number of subjects concerned out of the whole population; PEF: Peak expiratory flow liters per second (I. $\left.\mathrm{Sec}^{-1}\right)$; MEF 75 : Maximum expiratory flow rate at $75 \%$ of vital capacity, liters per second $\left(1 \cdot \mathrm{sec}^{-1}\right) ; \mathrm{MEF}_{50}$ : Maximum expiratory flow rate at $50 \%$ of vital capacity, liters per second $\left(1 \cdot \sec ^{-1}\right)$; SD: Standard deviation; TLC: Total lung capacity, liters (I); OR: Odds ratio.}

\section{Acknowledgements}

We want to thank the Finnish Respiratory Disease Research Foundation (Hengityssairauksien tutkimussäätiö), the Finnish Allergy Research Foundation (Allergiatutkimussäätiö), the Finnish Athletics Research Foundation (Urheilututkimussäätiö), Urheiluopistosäätiö, the Ida Montin Foundation (Ida Montinin Säätiö), the Ministry of Health and Social Affairs of Finland (Suomen Sosiaali ja Terveysministeriö) and the Ministry of Education and Culture (Opetusministeriö) for the financial support of this study. We also want to thank Robert M Badeau, MSc, PhD of Aura Professional English Consulting (www.aurae nglish.com), who performed this manuscript's language checking service. We also want to thank biostatistician Eliisa Löyttyniemi for giving statistical consultation.

\section{Authors' contributions}

MP performed the measurements collected and analyzed the data, wrote the main manuscript and prepared the figures and tables. All authors participated in study planning and in the reviewing and commenting on the text. MP, TP, PK, UK and HT participated in applying for study funding. TP and PK according to their expertise, commented the environmental aspects of the study. HT and UK according to their expertise, commented the medical aspects and sports medicine issues. MP and KK according to their expertise commented the sports science, physiological and swimming-specific issues. TP, PK, UK and HT participated in the administrational tasks of the research project. All authors read and approved the final manuscript. 


\section{Funding}

The funding received for this study are given by: The Finnish Respiratory Disease Research Foundation, The Finnish Allergy Research Foundation, The Finnish Athletics Research Foundation, Urheiluopistosäätiö, The Ida Montin Foundation, The Ministry of Health and Social Affairs of Finland, The Ministry of Education and Culture.

\section{Availability of data and materials}

Data is not available due to the datasets generated and analyzed during the current study are not publicly available due to the regulations of ethical committee statement but are available from corresponding author upon a reasonable request. However, the raw data availability is not possible to be provided to those not involved with the study. This is stipulated by the ethical committee of Helsinki and Uusimaa hospital district, which approved the testing protocol. Permission to deliver study data to non-study personnel requires a new application for the ethical committee and new approval to deliver raw data outside the corresponding study personnel.

\section{Declarations}

\section{Ethics approval and consent to participate}

Ethics approval from the ethical committee of Helsinki and Uusimaa hospital district and consent to participate were included in this study. All measurements were carried out in accordance with relevant guidelines and regulations of American Thoracic Society (ATS) and European Respiratory Society (ERS). Informed consent was obtained from all study subjects participating pulmonary function testing. Informed consent was obtained from a parent or a legal guardian for participants under 18 years.

\section{Consent for publication}

Not applicable.

\section{Competing interests}

There are no competing interests by any of the authors of this study.

\section{Author details}

${ }^{1}$ Department of Occupational Medicine, Faculty of Medicine, University of Turku, Turku, Finland. ${ }^{2}$ Institute of Clinical Medicine, Faculty of Medicine, University of Helsinki, Helsinki, Finland. ${ }^{3}$ Faculty of Sport and Health Sciences, University of Jyväskylä, Jyväskylä, Finland. ${ }^{4}$ Department of Environmental and Biological Sciences, University of Eastern Finland, Kuopio, Finland. ${ }^{5}$ School of Medicine, Institute of Biomedicine/Sports and Exercise Medicine, University of Eastern Finland, Kuopio, Finland.

Received: 20 November 2020 Accepted: 22 September 2021

Published online: 04 October 2021

\section{References}

1. Potts JE. Adverse respiratory health effects of competitive swimmers: the prevalence of symptoms, illnesses, and bronchial responsiveness to methacholine and exercise. Vancouver: University of British Columbia; 1994.

2. Potts J. Factors associated with respiratory problems in swimmers. Sports Med. 1996;21:256-61.

3. Helenius IJ, Rytilä P, Metso T, Haahtela T, Venge P, Tikkanen HO. Respiratory symptoms, bronchial responsiveness, and cellular characteristics of induced sputum in elite swimmers. Allergy. 1998;53:346-52.

4. Helenius I, Haahtela T. Allergy and asthma in elite summer sport athletes. J Allergy Clin Immunol. 2000;106:444-52.

5. Helenius I, Rytilä P, Sarna S, Lumme A, Helenius M, Haahtela RV, T, Effect of continuing or finishing high-level sports on airway inflammation, bronchial hyperresponsiveness, and asthma: a 5-year prospective follow-up study of 42 highly trained swimmers. J Allergy Clin Immunol. 2002;109:962-8.

6. Bernard A, Carbonnelle S, de Burbure C, Michel O, Nickmilder M. Chlorinated pool attendance, atopy, and the risk of asthma during childhood. Environ Health Perspect. 2006;114(10):1567-73.
7. Romberg K, Tufvesson E, Bjermer L. Asthma symptoms, mannitol reactivity and exercise-induced bronchoconstriction in adolescent swimmers versus tennis players. J Asthma Allergy. 2017;10:249-60.

8. Boulet LP. Cough and upper airway disorders in elite athletes: a critical review. Br J Sports Med. 2012;46(6):417-21.

9. Gomà A, de Lluis R, Roca-Ferrer J, Lafuente J, Picado C. Respiratory, ocular and skin health in recreational and competitive swimmers: beneficial effect of a new method to reduce chlorine oxidant derivatives. Environ Res. 2017;152:315-21.

10. Fitch KD, Morton AR. Specificity of exercise in exercise-induced asthma. $\mathrm{Br}$ Med J. 1971:4(5787):577-81.

11. Fitch KD, Morton AR, Blanksby BA. Effect of swimming training on children with asthma. Arch Dis Child. 1976;51:190-4.

12. Matsumoto I, Araki H, Tsuda K, Odajima H, Nishima S, Higaki Y, Tanaka $H$, Tanaka M, Shindo M. Effects of swimming training on aerobic capacity and exercise induced bronchoconstriction in children with bronchial asthma. Thorax. 1999;54(3):196-201.

13. Goodman M, Hays S. Asthma and swimming: a meta-analysis. J Asthma. 2008;45(8):639-47.

14. Rosimini C. Benefits of swim training for children and adolescents with asthma. J Am Acad Nurse Pract. 2003;15(6):247-52.

15. Font-Ribera L, Villanueva CM, Nieuwenhuijsen MJ, Zock JP, Kogevinas M, Henderson J. Swimming pool attendance, asthma, allergies, and lung function in the Avon Longitudinal Study of Parents and Children cohort. Am J Respir Crit Care Med. 2011;183(5):582-8.

16. Weisgerber MC, Guill M, Weisgerber JM, Butler $\mathrm{H}$. Benefits of swimming in asthma: effect of a sessionof swimming lessons on symptoms and PFTs with review of literature. J Asthma. 2003;40(5):453-64.

17. Bar-Or O, Inbar O. Swimming and asthma. Benefits and deleterious effects. Sports Med. 1992;14(6):397-405.

18. Bar-Yishay E, Gur I, Inbar O, Neuman I, Dlin RA, Godfrey S. Differences between swimming and running as stimuli for exercise-induced asthma. Eur J Appl Physiol. 1982;48(3):387-97.

19. Bougault $V$, Turmel J, Levesque B, Boulet LP. The respiratory health of swimmers. Sports Med. 2009;39(4):295-312.

20. Drobnic F, Freixa A, Casan P, Sanchis J, Guardino X. Assessment of chlorine exposure in swimmers during training. Med Sci Sports Exerc. 1996:28(2):271-4.

21. Päivinen MK, Keskinen KL, Tikkanen HO. Swimming and asthma: factors underlying respiratory symptoms in competitive swimmers. Clin Respir J. 2010;4(2):97-103.

22. Päivinen M, Putus T, Kalliokoski P, Tikkanen H. Airway obstruction in competitive swimmers. Health. 2013;5:460-4.

23. Päivinen MK, Keskinen KL, Tikkanen HO. Swimming and asthma: Differences between women and men. J Allergy 2013; 520913.

24. Hery M, Hecht G, Gerber JM, Gendre JC, Hubert G, Rebuffaud J. Exposure to chloroamines in the atmosphere of indoor swimming pools. Ann Occup Hyg. 1995;39:427-39.

25. Ferris BG. Epidemiology standardization project. Am Rev Respir Dis. 1978;118(suppl):7-53.

26. Miller MR, Hankinson J, Brusasco V, Burgos F, Casaburi R, Coates A, Crapo R, Enright P, van der Grinten CP, Gustafsson P, Jensen R, Johnson DC, Maclntyre N, McKay R, Navajas D, Pedersen OF, Pellegrino R, Viegi G, Wanger J. ATS/ERS task force. Standardisation of spirometry E Respir J. 2005;26:319-38.

27. Pedersen OF, Wanger J. Interpretative strategies for lung function tests. Eur Respir J. 2005;26(5):948-68.

28. Viljanen AA, Halttunen PK, Kreus K-E, Viljanen BC. Spirometric studies in non-smoking, healthy adults. Scand J Clin Invest. 1982;159:5-20.

29. Koillinen H, Vanne O, Niemi V, Laakkonen E. Terveiden suomalaisten lasten spirometrian ja uloshengityksen huippuvirtauksen viitearvot. Suom Laakaril. 1998:39:395-402.

30. Kalliokoski P, Rahkonen T, Mäkinen M, Rantio T, Säämänen A, Rautiala $\mathrm{S}$, Jauhiainen $\mathrm{T}$, Vilve $\mathrm{M}$, Hyttinen $\mathrm{M}$, Kokotti $\mathrm{H}$, Kettunen $\mathrm{R}$, Keskitalo $\mathrm{P}$, Korpi A. Uimahallien veden laatuun kohdistettujen toimenpiteiden vaikutus henkilökunnan työolosuhteisiin. Kuopion yliopiston ympäristötieteiden laitoksen monistesarja. 2009; 3.

31. Raunemaa T, Yli-Pirilä P, Hirvonen A, Nuutinen J, Päivinen M, Kujala U, Jauhiainen T., Korpi A, Halonen R, Kokotti H, Keskikuru T. Uimahallien aerosolipitoisuudet ja koostumus, ilmanjako, vedenkäsittely sekä 
uimahallin käyttäjien hengitystiealtistuminen. Kuopion yliopiston ympäristötieteiden laitosten monistesarja 2005; 6.

32. Patovirta RL, Reiman M, Husman T, Haverinen U, Toivola M, Nevalainen A. Mould specific IgG antibodies connected with sinusitis in teachers of mould damaged school: a two-year follow-up study. Int J Occup Med Environ Health. 2003;16(3):221-30.

33. Magel JR, Faulkner JA. Maximum oxygen uptakes of college swimmers. J Appl Physiol. 1967;22(5):929-33.

34. Cordain L, Stager J. Pulmonary structure and function in swimmers. Sports Med. 1988;6(5):271-8.

35. Silvestri M, Crimi E, Oliva S, Senarega D, Tosca MA, Rossi GA, Brusasco V. Pulmonary function and airway responsiveness in young competitive swimmers. Pediatr Pulmonol. 2013;48(1):74-80
36. Wells GD, Schneiderman-Walker J, Plyley M. Normal physiological characteristics of elite swimmers. Pediatr Exerc Sci. 2006;17:30-52.

37. Rundell KW, Wilber RL, Szmedra L, Jenkinson DM, Mayers LB, Im J. Exercise-induced asthma screening of elite athletes: field versus laboratory exercise challenge. Med Sci Sports Exerc. 2000;32(2):309-16.

38. Dickinson JW, Whyte GP, McConnell AK, Harries MG. Impact of changes in the IOC-MC asthma criteria: a British perspective. Thorax. 2005;60(8):629-32.

\section{Publisher's Note}

Springer Nature remains neutral with regard to jurisdictional claims in published maps and institutional affiliations.
Ready to submit your research? Choose BMC and benefit from:

- fast, convenient online submission

- thorough peer review by experienced researchers in your field

- rapid publication on acceptance

- support for research data, including large and complex data types

- gold Open Access which fosters wider collaboration and increased citations

- maximum visibility for your research: over 100M website views per year

At BMC, research is always in progress.

Learn more biomedcentral.com/submissions 